Vol. 44, N. 4 : pp. 405 - 410, December, 2001

ISSN 1516-8913 Printed in Brazil

\title{
Submicroscopical Features of Leaves of Xyris Species
}

\author{
Maria das Graças Sajo ${ }^{1 *}$ and Silvia Rodrigues Machado ${ }^{2}$ \\ ${ }^{I}$ Depto de Botânica, IBUNESP, Caixa Postal 199. 13506-900 Rio Claro - SP, Brazil; ${ }^{2}$ Depto de Botânica, IBUNESP, \\ Caixa Postal 510. 18618-000 Botucatu - SP, Brazil
}

\begin{abstract}
The leaf ultrastructure of five Xyris species were examined using scanning electron microscope (SEM), transmission electron microscope (TEM) and histochemical methods. All studied leaves show some features in epidermis and mesophyll, which were of considerable adaptative significance to drought stress. Such features included the occurrence of a pectic layer on the stomatal guard cells and the presence of a network of pectic compounds in the cuticle. Pectic compunds were also in abundance in lamellated walls of the mesophyll cells and on the inner surface of the sclerified cell walls of the vascular bundle sheaths. There were also specialized chlorenchymatous "peg cells" in the mesophyll and drops of phenolic compounds inside the epidermal cells.
\end{abstract}

Key words: Xyris, ultrastructure, leaf

\section{INTRODUCTION}

Xyris L. is the largest genus of the neotropical family Xyridaceae (Kral, 1988). In Brazil, the species of Xyris are almost restricted to the vegetation called "campos rupestres", which literally means stone fields and predominated in the Espinhaço Range (center of Brazil). In these fields, Xyris species are often associated with Poaceae species growing on stone/sandy soils where the drainage is impeded and oligotrophic bogs may occur, occasionally forming peat-hags. In the Espinhaço Range, the climate is characterized by a dry period of three-four months in the winter (Giulietti \& Pirani, 1988).

Xyris leaves have an ensiform unifacial blade that develops by an extensive activity of the adaxial meristem (Sajo \& Rudall, 1999). The thick blades vary from ensiform to cylindrical and show fused vascular bundles surrounded by sclerenchymatous cells (Sajo, 1992, Sajo et al., 1995, Sajo \& Wanderley, 1998).
Although Machado \& Sajo (1996 a, b) described submicroscopical features in Xyris leaves, the ultrastructure of most species are still unknown. This paper presents new observations on leaf ultrastrucuture of five Brazilian species of Xyris, and interprets some features as adaptative to dry habitats.

\section{MATERIALS AND METHODS}

Plant materials were collected from Serra do Cipó, State of Minas Gerais, Brazil. The vouchers of Xyris hymenachne Mart., Xyris obcordata Kral and Wanderley, Xyris paraensis Poepp and Xyris pterygoblephara Steud. are deposited at IBUNESPRio Claro Herbarium (HRCB numbers 16671, 16657, 16694 and 19553 respectively); the vouchers of Xyris tortilis Wanderley are deposited at ICBUFMG Herbarium (BHCB 19421).

Samples from the median region of mature leaves were fixed in $2.5 \%$ glutaraldehyde using a $0.1 \mathrm{M}$ phosphate buffer $(\mathrm{pH} 7.8)$ and postfixed in $1 \% \mathrm{OsO}_{4}$

* Author for correspondence 
using the same buffer. For TEM observations, fixed materials were dehydrated in acetone and embedded in Araldite. Ultrathin sections were contrasted with uranyl acetate and lead citrate (Reynolds, 1963) and examined with a Philips EM 302 transmission electron microscope. For SEM observations fixed materials were dehydrated through alcohol series to absolute alcohol, and critical-point-dried samples, mounted on stubs and coated with $\mathrm{Au} / \mathrm{Pd}$. Freehand sections of fresh material were treated with ruthenium red for histochemical identification of pectic substances and with $\mathrm{FeCl}_{3}$ for phenolic compounds identification (Johansen, 1940).

\section{RESULTS AND DISCUSSION}

All studied species grow on shallow stony/sandy soil in an open environment at $900 \mathrm{~m}$ above the sea level and are subjected to drougth stress during four months per year.

The evergreen unifacial leaves are covered by one layered epidermis (Sajo et al., 1995) cells presented condensed phenolic compounds in $X$. pterygoblephara, X. tortilis, X. obcordata and X. hymenachne, (Fig. 1-3, 6 arrow), as reported for Eragrostis racemosa from dry habitats (Theunissen \& Jordan, 1990). According to Fahn \& Cutler (1992), the appearence of tannins in leaf cells has been considered to be of adaptative value in xeromorphytic conditions. Mole et al. (1988) also associated the presence of phenolics and condensed tannins with high levels of light intensity. As the studied species are exposed to high light intensity and to a dry season, the presence of phenolic compounds probably could be associated with both environmental stress.

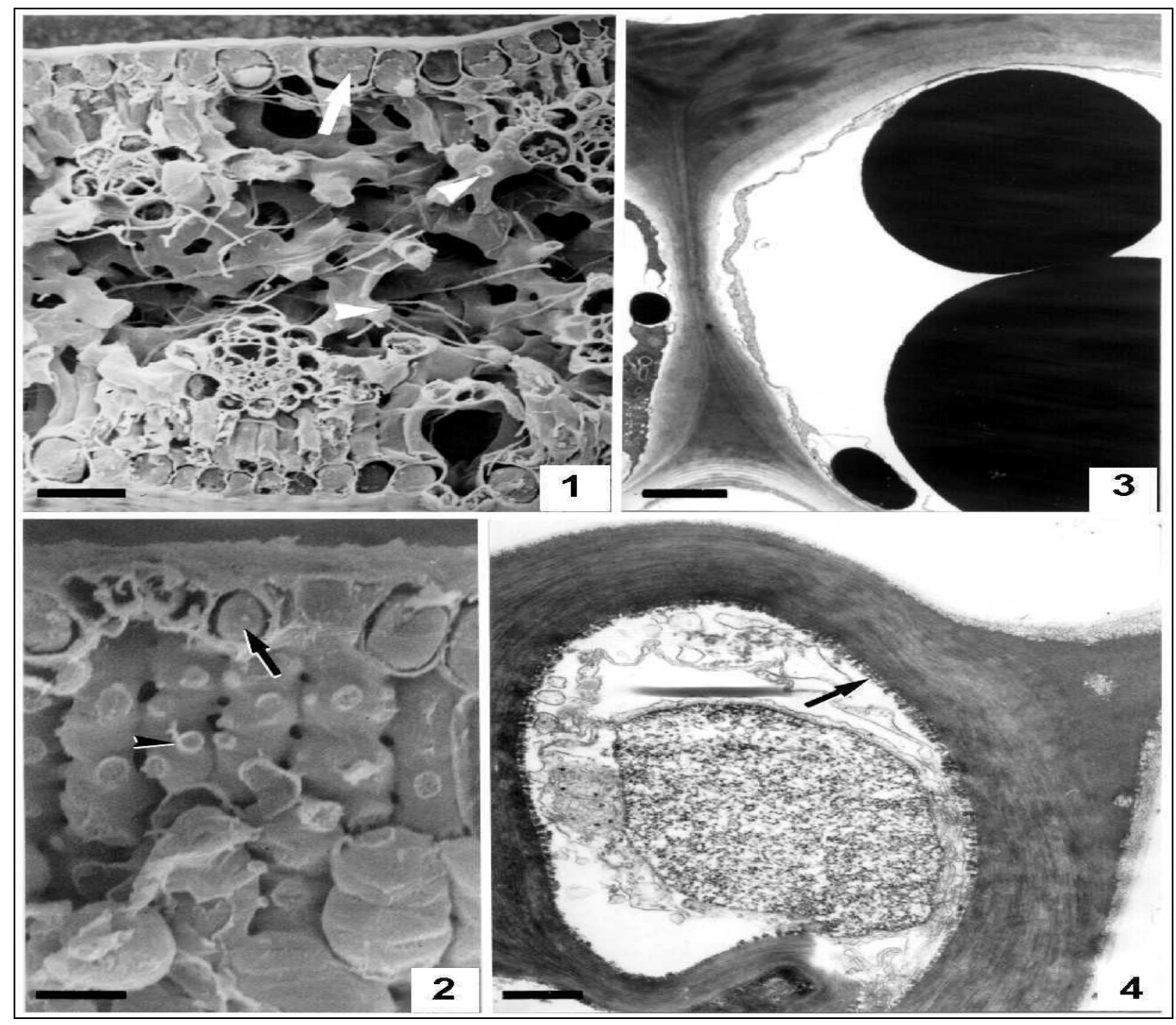

Figures 1-4 - Xyris leaves in cross section. 1. X. pterygoblephara (SEM). 2. X. tortilis (SEM). Epidermis cells with condensed phenolic compounds (arrows) and mesophyll cells with undulant lateral walls forming pegs (arrowhead). 3. $X$. obcordata (TEM). Epidermal cell with phenolic compounds on lamellated wall and inside its protoplast. 4. $X$. hymenachne (TEM). Stomata guard cell covered by a protective layer (arrow). Bars: $1=31 \mu \mathrm{m} ; 2=10 \mu \mathrm{m} ; 3=2,2 \mu \mathrm{m} ; 4$ $=0,5 \mu \mathrm{m}$. 
Phenolic deposits were also observed as electron dense stripes in the outer periclinal lammellated walls of epidermis cells in leaves of $X$. obcordata (Fig. 3), X. pterygoblephara and X. hymenachne, as reported for Myrothamnus flabelifolia by Pizzi \& Cameron (1986). The authors suggested that the helicoidal three dimensional structure of the polyflavonoid tannins function as "springs", which prevented cracking of the cell walls under drought stress.

In X. hymenachne (Fig. 4), the walls of the stomata guard cells were covered internally by a special layer, called protective layer (O'Brien, 1970) or secondary cellulosic layer (Czaninskiy, 1973), which was reported for the parenchymatous cells of the secondary xylem by Barnett et al. (1993), Chaffe (1974), Foster

(1967) and Wisniewski \& Davis (1989). Such a protective layer formed electron dense ramified clusters (Fig. 4, arrow) which were permeated with pectic compounds. As the protective layer is supposed to increase the water/nutrients movement via apoplast (Barnett et al., 1993) in Xyris hymenachne it may facilitate the hydroactive function of the stomatal cells.

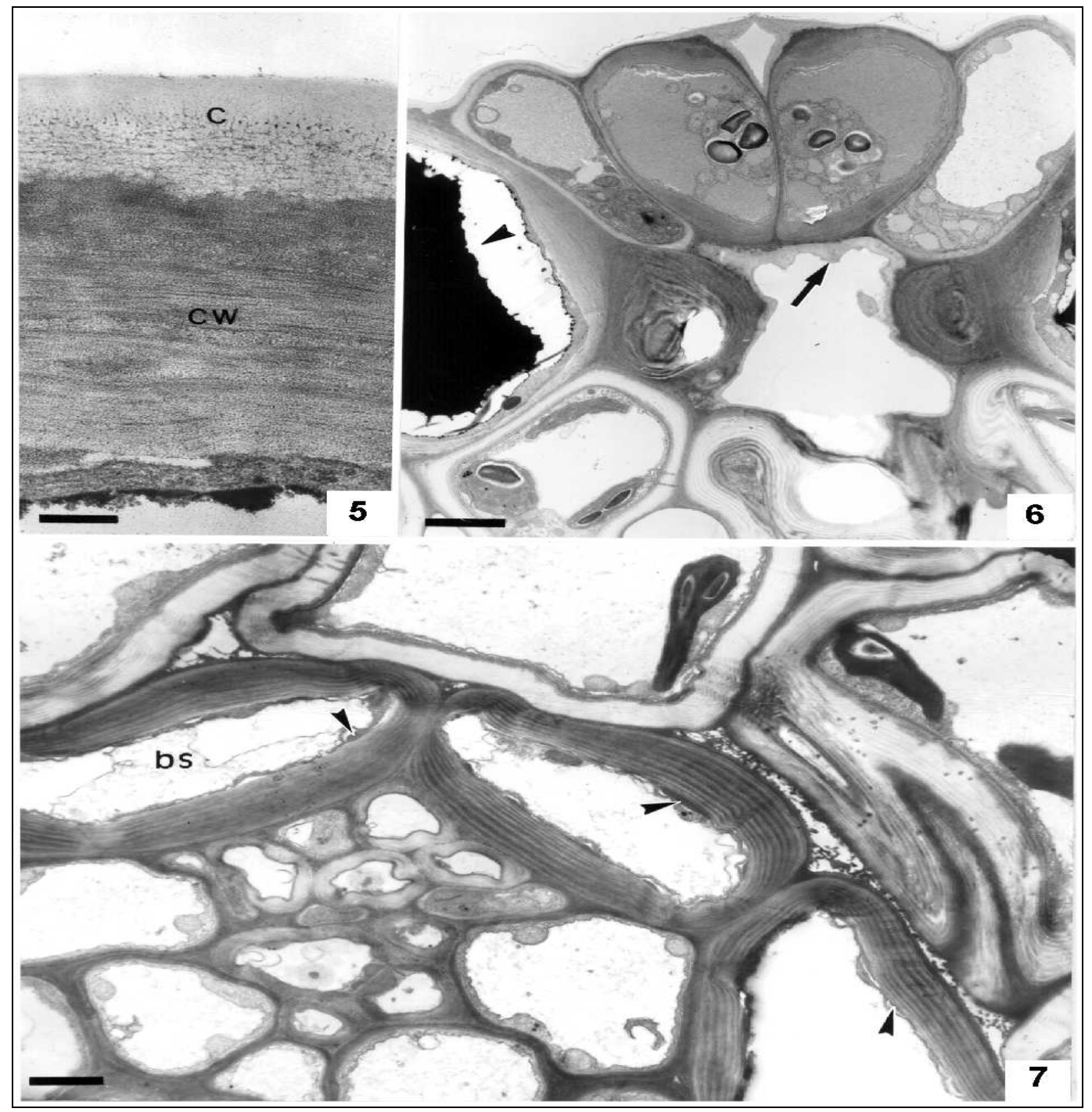

Figures 5-7 - Xyris leaves in cross section (TEM). 5. X. tortilis. Detail of an epidermal cell wall (CW) showing a network of pectic compounds in the cuticular layer (C). 6. X. hymenachne. Stomata with a thick cuticle which also cover the substomatal chamber (arrow). Note the phenolic compounds inside epidermal cells (arrowhead). 7. X. tortilis. Cells of mesophyll and vascular bundle sheath (bs) with lamellated walls. The arrowheads show inner protuberances of pectic nature. Bars: $5=0,18 \mu \mathrm{m} ; 6=2,3 \mu \mathrm{m} ; 7=1,5 \mu \mathrm{m}$. 
Although most of the leaves have a thin amorphous cuticle, in $X$. hymenachne and $X$ tortilis, the cuticle was thick and showed an amorphous cuticle proper and a cuticular layer with a reticulum of pectinous electron-dense lines connected to the pectin layer (Fig. 5, c).

Such a cuticle was of Type 3 in Holloway (1982) classification and was also reported for Agave americana, Andisia crenata and Vaccinium reticulatum by Lyshede (1982). Although the type of cuticle structure is not related to a determinated ecotype (Jefree, 1986), the pectin networks probably function in the hydration of the cell walls, as the pectic substances have hydrophilic properties.

The cuticle formed a protuberance above the stomatal opening and covered the cell walls of the substomatal chamber in X. tortilis (Fig. 6, arrow).

The cells of the mesophyll and of the vascular bundles sheath had thickened lamellated walls (Figs 7-10), which were formed because of dry habitats. According to Brett \& Waldron (1996) the lamellated patern of wall deposition occurred as a response to some stress. In the vascular bundles sheath the cell walls were sclerified and show inner protuberances of pectic nature (Fig. 7).

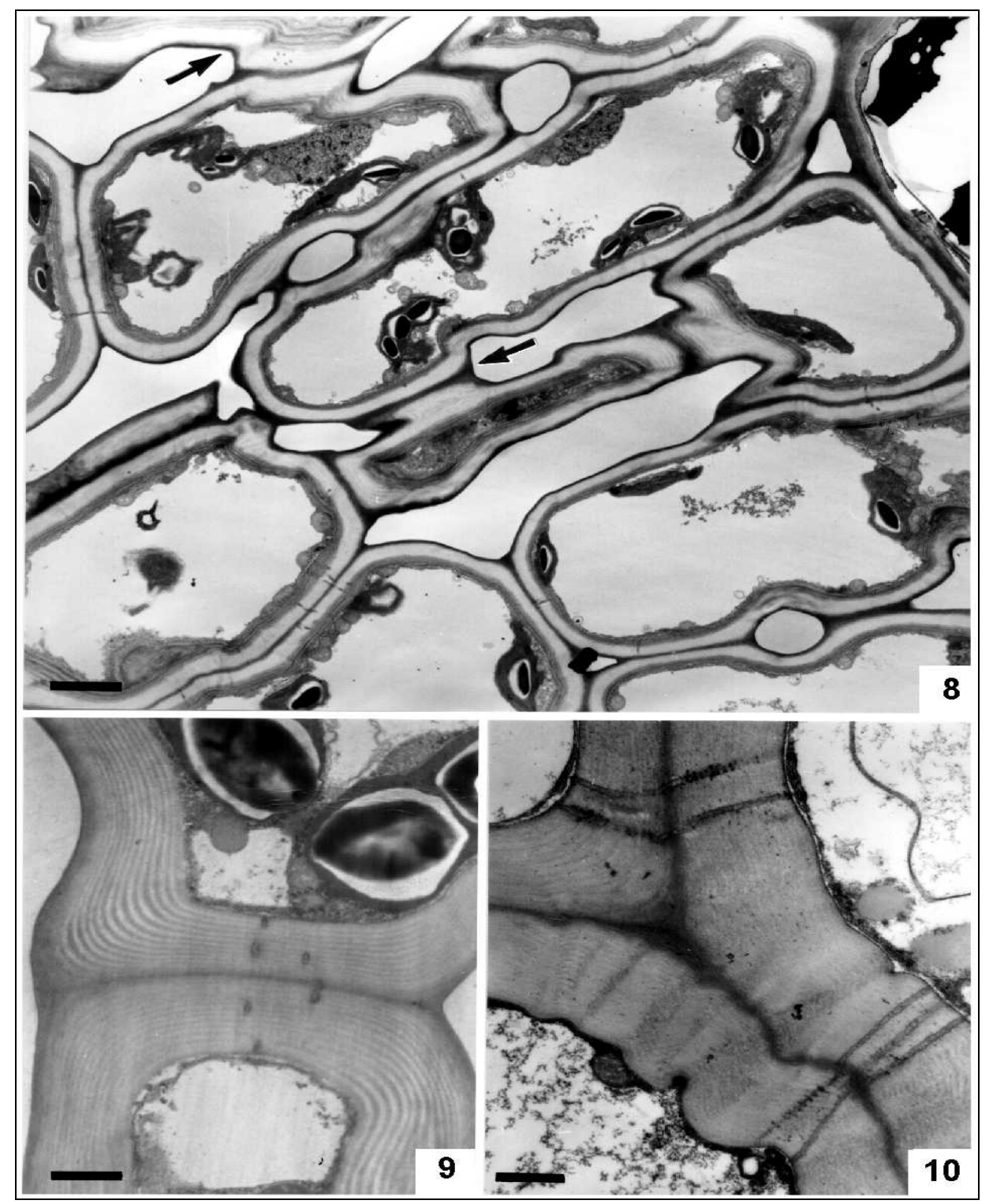

Figures 8-10 - Xyris tortilis leaf in cross section (TEM). 8. Mesophyll clorenchyma peg-cells with lamellated walls (arrow). 9-10. Peg details showing lamellated undulant walls and plasmodesmata. Bars: $8=3,0 \mu \mathrm{m} ; 9=1 \mu \mathrm{m} ; 10=0,6$ $\mu \mathrm{m}$. 
According to Jauneau et al. (1998) were one of the most important components of the cell wall matrix and contributed to cell adhesion via its gel-like properties (Jarvis, 1984) and to cell architecture (Brett \& Waldron, 1996).

Although pectic compounds were not specifically associated with drought stress, their generalized occurrence in Xyris leaves suggested that the species were able to store small amounts of water avoiding the drought stress they were exposed to during the winter.

In all studied species, the mesophyll showed a palisade tissue close to the surface and spongy parenchyma in the center (Sajo et al., 1995). Some chlorenchyma cells were approximately cylindrical in shape, with undulant lateral walls forming alternate inward and outward folds. Along the outer edge of each outward fold, the wall was thickened where the matching outward fold of the adjacent cell (Fig. 8-9). The nature of these thickenings was an additional pectic and cellulosic wall deposit. Adjacent cells adhered only along these regularly aligned thickenings (Fig. 1-2), which accommodated all plasmodesmata (Fig. 9-10), and were separated elsewhere. In X. tortilis, all layers of the mesophyll displayed such cells; and in the other species they were evident only in the palisade layer.

These characteristic cells were similar to the pegcells described for Restionaceae stems and occurred in plants surviving in dry habitats (Cutler, 1969). According to this author, the peg-cells provided a compact tissue with a large area of exposed surface through which gas exchange might tooke place.

According to Fahn \& Cutler (1992), the use of only the leaf size as an indicator for xeromorphy was insufficient and the volume and organisation of the mesophyll tissues should be taken into consideration.Moreover, a low surface to volume ratio as observed in unifacial leaves of Xyris were characteristic of photossynthesinzing organs of xerophytes. The reduction of external leaf surface and the presence of sclerenchyma in the mesophyll (Sajo, 1992, Sajo et al., 1995, Sajo \& Wanderley, 1998) in association with the occurrence of cells with phenolic and pectic compounds, as observed in the present study, were related to xeromorphic leaves whose strategy of adaptation led to the reduction in the transpiratory and photosynthetic rates (Fanh \& Cutler, 1992). In Xyris leaves such strategy could also be expressed by the condensed phenolic compounds inside the epidermis cells, the mesophyll with chlorenchymatous peg-cells and the occurrence of polylamellated cell walls of pectic nature.

\section{RESUMO}

Foi estudada a ultra-estrutura foliar de cinco espécies brasileiras de Xyris, utilizando microscópio eletrônico de varredura (MEV), microscópio eletrônico de transmissão (MET) e métodos histoquímicos. Na epiderme e mesofilo de todas as folhas estudadas encontram-se caracteres que podem ser interpretados como adaptativos a condições xéricas. Tais caracteres incluem a presença de uma camada parietal interna de natureza péctica nas células oclusivas e a ocorrência de finas ramificações elétron-densas, também de natureza péctica, formando uma rede na camada cuticular. Compostos pécticos também são freqüentes nas paredes lameladas das células do mesofilo e na superfície interna das paredes esclerificadas das células da bainha dos feixes vasculares. Ocorrem, ainda, acúmulos de compostos fenólicos no vacúolo das células epidérmicas e células especializadas no mesofilo, denominadas "peg cells".

\section{REFERENCES}

Barnett, J. R.; Cooper, P. and Bonner, L. (1993), The protective layer as an extension of the apoplast. IAWA Journal, 14(12), 163-171.

Brett, C. and Waldron, K. (1996), Physiology and biochemistry of plant cell walls. London: Chapman and Hall.

Chaffe, S. C. (1974), Cell formation and protective layer development in the xylem parenchyma of trembling aspen. Protoplasma, 89, 335-354.

Cutler, D. F. (1969), Anatomy of monocotyledons IV Juncales. Oxford: Claredon Press.

Czaninskiy, Y. (1973), Observations sur une nouvelle couche pariétale dans les cellules associées aux vaisseaux du Robinier et du Sycomore. Protoplasma, 77, 211-219.

Fah, A. and Cutler, D. F. (1992), Xerophytes. InEncyclopedia of plant anatomy, Vol. XIII, eds J. Braun; S. Carlquist; P. Ozenda; I. Roth. Berlin: Gebrüder Borntraeger.

Foster, R. C. (1967), Fine structure of tyloses in three species of Myrtaceae. Aust. J. Bot., 15, 25-34.

Giulietti, A. M. and Pirani, J. R. (1988), Patterns of geographic distribution of some plant species from Espinhaço Range, Minas Gerais and Bahia, Brasil. InProceedings of a workshop of neotropical distribution patterns, eds P. E. Vanzolini; W. R. Heyer. Rio de Janeiro: Academia Brasileira de Ciências, 39-69. 
Holloway, P. J. (1982), Structure and histochemistry of plant cuticular membranes: an overview. In-The Plant Cuticle, eds D. F. Cutler; K. L. Alvin; C. E. Price. London: Academic Press, 1-32.

Jarvis, M. C. (1984), Structure and properties of pectin gels in plant cell walls. Plant Cell Environ., 7, 153-164.

Jauneau, A.; Roy, S.; Reis, D. and Vian, B. (1998), Probes and microscopical methods for the localization of pectins in plant cells. Int. J. Plant Sci., 159, 1-13.

Jefree, C. E. (1986), The cuticle, epicuticular waxes and trichomes of plants, with reference to their structure, functions and evolution. In-Insects and the plant surfaces, eds B. Juniper; R. Southwood. London: Edward Arnold, 22-64.

Johansen, D. A. (1940), Plant microthechnique. New York: McGraw-Hill.

Kral, R. (1988), The genus Xyris (Xyridaceae) in Venezuela nad contiguous northern South America. Ann. Mo Bot. Gard., 75, 522-722.

Lyshede, O. B. (1982), Structure of the outer epidermal wall in xerophytes. In-The plant cuticle, eds D. F. Cutler; K. L. Alvin; C. E. Price. London: Academic Press, 87-97.

Machado, S. R. and Sajo, M. G. (1996a), Occurrence of form PIIcf sieve-element plastids in Xyris species (Xyridaceae). Ann. Bot., 78, 671-673.

Machado, S. R. and Sajo, M. G. (1996b), Intercellular pectic protuberances in leaves of some Xyris species (Xyridaceae). Can. J. Bot., 74, 1539-1541.

Mole, S.; Rosso, J. A. M. and Waterman, P. G. (1988), Light-induced variation in phenolic levels in foliage of rain-forest plants. I. Chemical changes. J. Chem. Ecol., 14, 1-21.
O'Brien, T. P. (1970), Further observations on hydrolysis of the cell wall in the xylem. Protoplasma, 69, 1-14.

Pizzi, A.; Cameron, F. A. (1986), Phlavonoid tannins structural wood components for drought - resistance mechanisms of plants. Wood Sci., 20, 119-124.

Reynolds, E. S. (1963), The use of lead citrate at high $\mathrm{pH}$ as an electron-opaque stain in electron microscopy. $J$. Cell Biol., 17, 208-212.

Sajo, M. G. (1992), Estudos morfoanatômicos em órgãos foliares de Xyris L. (Xyridaceae). Bol. Botânica, Univ. São Paulo, 13, 67-86.

Sajo, M. G. and Wanderley, M. G. L. (1998), Estrutura foliar e a taxonomia de 5 táxons de Xyris L. (Xyridaceae). Bol. Botânica, Univ. São Paulo, 17, 31-38.

Sajo, M. G. and Rudall, P. J. (1999), Systematic vegetative anatomy and ensiform leaf development in Xyris (Xyridaceae). Bot. J. Linn. Soc., 130, 171-182.

Sajo, M. G.; Wanderley, M. G. L. and Carvalho, L. M. (1995), Caracterização anatômica foliar para 14 espécies de Xyris L. (Xyridaceae) da Serra do Cipó, MG, Brasil. Acta bot. bras., 9(1), 101-114.

Theunissen, J. D. and Jordan, A. (1990), Histochemical localization of phenolic deposits in leaf blades of Eragrostis racemosa. Ann. Bot., 65, 633-636.

Wisniewski, M. and Davis, G. (1989), Evidence for the involvement of a specific cell wall layer in regulation of deep supercooling of xylem parenchyma. Plant Physiol., 91, 151-156.
Received: June 13, 2000; Revised: October 05, 2000; Accepted: May 02, 2001. 